Article

\title{
Ulysses and the Signature of Things
}

\author{
Hunter Dukes \\ Faculty of English, University of Cambridge, Cambridge CB3 9DP, UK; hbd23@cam.ac.uk \\ Received: 13 June 2017; Accepted: 19 July 2017; Published: 24 July 2017
}

\begin{abstract}
James Joyce's depiction of autographic signatures resembles the "doctrine of signatures" - a pre-modern system of correspondence between medicinal plants and parts of the body. Certain aspects of this episteme reappear in the late nineteenth century. This recurrence is due, in large part, to developments in the technology of writing that threaten what Friedrich Kittler calls the "surrogate sensuality of handwriting." Reading the "Nausicaa" episode of Ulysses against fin-de-siècle ideas about graphology, I argue that signature offers a unique perspective on Joyce's taxonomic representation, which questions the boundaries between a body of text and (non)human bodies.
\end{abstract}

Keywords: James Joyce; Ulysses; graphology; signature; inscription; Michel Foucault; Giorgio Agamben; Walter Benjamin; Jakob Böhme

"There is no difference between marks and words ..."

-Michel Foucault (Foucault 2002, The Order of Things, p. 38)

\section{Initial Thoughts}

In James Joyce's A Portrait of the Artist as a Young Man, Stephen Dedalus and his father, Simon, take a trip to Cork. At one point during the weekend, they visit a classroom in Queen's College, where Simon attended university. Searching the wooden desks, Stephen finds two inscriptions: the word "Fœtus" and the initials "SD." As Stephen gazes upon the initials, they begin to stare back. "The letters cut in the stained wood of the desk stared upon him, mocking his bodily weakness and futile enthusiasms and making him loathe himself for his own mad and filthy orgies" (Joyce 1964, p. 91). The personified letters become tormentors, distinct from the sounds and meaning they are supposed to connote. They mock his strength, deflate his enthusiasms, and mediate the way Stephen views himself-making him "loathe" his past actions. They even cause an involuntary response, affecting Stephen's salivary glands, taste buds, and optical perception, as his spittle grows "bitter" in his throat and he is forced to close his eyes.

The debilitating effects seem to stem from the congruity between his own initials and those of his father, creating indeterminacy through identification. By recognizing the initials-which, turn out, to be letters written by Simon-Stephen becomes momentarily dispossessed of his signature. This correspondence between signatures expands into a correspondence between signatories, blurring the psychic boundaries between father and son. "His very brain was sick and powerless. [ ... ] He could scarcely recognise as his his own thoughts" (Joyce 1964, p. 92). The inscription denotes both Stephen and Simon, reflected through an ambiguous repetition of "his," clouding Stephen's judgment about who and where he is. Like the ligature that joins "o" and "e" in Joyce's use of "Fœtus"- a glyph that reflects the penultimate characters in "Simon" and "Stephen"- the Dedalus men become increasingly interwoven. Reading this second engraving, Stephen is overcome with a vision from his father's past.

The sudden legend startled his blood: he seemed to feel the absent students of the college about him and to shrink from their company [ ... ] A broad shouldered student with a moustache was cutting letters with a jack knife, seriously. Other students stood or sat near him laughing at his handiwork. (Joyce 1964, pp. 89-90) 
To look upon the inscription is to be transported back to its origin-the scene, Stephen imagines, as witnessed by his father. While Simon tries to convey a sense of his early life through conversation, it is only the carving (and its unique presence as a graphic body) that grants Stephen access to the past. Utilizing initials to think through notions of identity and resemblance, Joyce cryptically suggests that the son has gained momentary access to his father's memories by means of his signature.

Joyce's own son would later mirror the filial aspect of Stephen's anxiety, reprimanding James for initialing his books. "As he stamped each of his books with J.J. and put them into his suitcases, Giorgio suddenly protested, 'Don't do that. I'm going to have your books when you die, and your initials will be on them'" (Ellmann 1982, p. 465). Indicative of the psychology that accompanies signatory identification, Giorgio worries that he will not be able to truly inherit his father's books if they are initialized "JJ" instead of "GJ." Joyce himself placed particular faith in signatory congruence, finding, in later life, his trust in James Stephens confirmed by the author's initials. Writing to Harriet Shaw Weaver about his belief that Stephens should finish Finnegans Wake, Joyce describes how the title-page's initials might look. "JJ and S (the colloquial Irish abbreviation for John Jameson and Son's Dublin whiskey) would be nice lettering under the title" (Joyce 1957, pp. 253-54). Here the initials "JJ and S" invert the causality described in Portrait: affinity is reflected, rather than created, by Joyce and Stephens's conjoined initials. While Giorgio fears the difference between his initials and those of his father, Stephen reacts to their conformity-an identification that leads to a strange psychic porosity, casting the younger Dedalus into a state of disassociation.

Joyce's reverence for initials is part of a larger fascination with signatures, a form of mark making that appears frequently throughout his novels. The idea demonstrated above-that a set of shared initials might reflect (or even create) other kinds of correspondences-mimics a system of resemblance known as the doctrine of signatures. Certain aspects of this doctrine or episteme recur in the late nineteenth century. Reading various signatures in Ulysses against fin-de-siècle ideas about graphology, I argue that signature offers a unique perspective on Joyce's taxonomic representation, which questions the boundaries between a body of text and (non)human bodies. This idea is taken to its logical extreme in "Nausicaa," where scents, sounds, and impressions become bodily, as opposed to alphabetical, signatures_produced by humans, waves, and stones. "The body," writes Michel Serres, "is an extraordinarily complex system that creates language from information and noise, with as many mediations as there are integrating levels" (Serres 1982, p. 82). Just as Stephen and Simon's shared initials appear to mediate their psychic boundary, signature becomes a form of mediation without equivalence in Ulysses, integrating human, animal, and material bodies under a shared sign.

\section{Doctrines of Signature}

The third episode of Joyce's Ulysses begins within the consciousness of an older Stephen Dedalus, as he gazes out over Sandymount Strand. Once again, Stephen contemplates signatures-this time, however, they belong to the seaside.

Ineluctable modality of the visible: at least that if no more, thought through my eyes. Signatures of all things I am here to read, seaspawn and seawrack, the nearing tide, that rusty boot. Snotgreen, bluesilver, rust: coloured signs. ${ }^{1}$ (U 3.1-4)

In the second sentence, we are met with the title of Jakob Böhme's De Signatura Rerum (1651), translated as The Signature of All Things. Colleen Jaurretche is one of the few scholars to offer an extended reading of Böhme's presence in this "moment of introspective anti-enlightenment," which Stephen finds in the signature of things. While Jaurretche traces Stephen's search for "divine and personal manifestation" in the flotsam of Sandymount Strand, I want to abstract a system of correspondence from Böhme, and compare it explicitly to relationships of resemblance in Ulysses (Jaurretche 1997, pp. 90, 92).

1 The reference (Joyce 1986) will be cited as $U$ with the corresponding episode and line numbers (e.g., 3.1-4, chapter 3, line 1-4) in keeping with the conventions of the Gabler edition. 
Böhme's text combines Christian cosmology with systematic philosophy and magical beliefs about botany and metallurgy to express paradigm known as the doctrine of signatures. A theory of correspondence that preoccupied Western epistemology until the sixteenth century, notably espoused by Paracelsus in medical terms, the "doctrine" refers to a belief that knowledge could be derived from different types of resemblance-and that these resemblances could be identified through imprinted signatures. "There are no resemblances without signatures," writes Michel Foucault in The Order of Things. "The world of similarity can only be a world of signs" (Foucault 2002, p. 71). Foucault's reading of what he terms the pre-modern episteme describes a system of relations that parallels how Ulysses represents correspondence.

In its raw, historical sixteenth-century being, language is not an arbitrary system; it has been set down in the world and forms a part of it, both because things themselves hide and manifest their own enigma like a language and because words offer themselves to men as things to be deciphered. The great metaphor of the book that one opens, that one pores over and reads in order to know nature, is merely the reverse and visible side of another transference, and a much deeper one, which forces language to reside in the world, among the plants, the herbs, the stones, and the animals. (Foucault 2002, pp. 38-39)

Before representation overshadowed resemblance, creating an arbitrary relationship between a sign and its referent, language was a part of the world—at least, according to this origin story. To "read" certain features in a landscape was an act alike in kind to reading a text. Most importantly, language was continuous with herbs, stones, and animals, as these entities possessed signatures that, with the right technique, could be read and deciphered.

To take an example from the medical sphere, Euphrasia or eyebright, a plant long believed to aid eyesight, has a visual signature that mirrors the shape of an eye. As Paracelsus, whose name appears amidst others in "Cyclops," writes: "Why does Euphrasia cure the eyes? Because it has in itself the anatomiam oculorum; it has in itself the shape and image of the eyes, and hence it becomes entirely eye" (U 12.188; Agamben 2009, p. 37) To become entirely eye is a process distinct from representation-it implies that eyebright and the human eye are entangled through a divine chain or system. "Signatures are, as Henry More wrote almost a century after Paracelsus' death, 'natural hieroglyphics,' through which God reveals medicinal virtues hidden in the vegetal world" (Agamben 2009, p. 36). All things, animals, and people manifest their invisible qualities through visible signatures-the trick comes in knowing where to look and how to interpret the hieroglyphic world.

At the center of the doctrine of signatures we find two entwined beliefs. First that, like Dorian Gray's portrait, whose painted face manifests the hidden, inner state of his corrupted soul, the interior or unseen world expresses itself through an external means. In the nonhuman world, the physical appearances of animal, plant, and mineral entities (color, form, pattern, and texture) reveal important aspects of their relational character. The second constituent belief is that, since appearance is a manifestation of content and quality, a correspondence between signatures can reveal other connections and interrelations that are not immediately perceptible or sensuous. By signature, then, Paracelsus and Böhme mean something more than a name written upon a page or initials engraved in a desk-although, as I will argue, Joyce's conception of autography inherits features from this older form.

Leopold Bloom is familiar with this medical doctrine, as it forms the intuitive basis for his navigation of Sweny's pharmacy in "The Lotus Eaters." "Test: turns blue litmus paper red. Chloroform. Overdose of laudanum. [ ... ] Paragoric poppysyrup bad for cough" (U 5.481-3). Paragoric syrup evokes Chlorodyne-a mixture of chloroform, laudanum, and cannabis—a well-known patent medicine in late nineteenth century. While litmus paper colors red in acidic environments, Bloom's mind connects the positive test to the presence of red poppies. The subsequent "homely recipes" of health rely upon a similar system of visual correspondence. Bloom remembers that oatmeal steeped in buttermilk is good for the skin — what he calls "skinfood"—-because the substance looks like his targeted organ. Likewise "strawberries for the teeth" are recommended because the berry approximates the shape of a human tooth (U 5.496-7). Remembering how benzoin tincture and orangeflower water 
make Molly's skin "white like wax," Bloom decides to purchase white wax to bring out the darkness of her eyes (U 5.492). Here we find the laws of attraction that structure the doctrine of signatures. Since Molly's skin resembles wax, it follows that wax would produce beneficial results when applied to her skin.

While this doctrine approximates a "motivated" relationship on the linguistic plane-where the word-image attempts to represent its semiotic content through sound symbolism, iconism, or another logic of mimesis-it is important to preserve the expanded, pre-modern sense of correspondence from being made synonymous with modern ideas about representation. "The medieval conceptualization of representare did not see it as the substitution for something that is absent by means of acoustic or pictorial signs," writes Bernhard Siegert. "Rather, it meant that something absent was made present by way of physical embodiment" (Siegert 2015, p. 58). This is the thrust of Giorgio Agamben's argument in "Theory of Signatures," part of an essay trilogy in which he responds to Foucault's The Order of Things.

The relationship is not between a signifier and signified (signans and signatum). Instead, it entails at least four terms; the figure in the plant, which Paracelsus often calls signatum; the part of the human body; the therapeutic virtue; and the disease-to which one has to add the signator as a fifth term. Signatures, which according to the theory of signs should appear as signifiers, always already slide into the position of the signified, so that signum and signatum exchange roles and seem to enter into a zone of undecidability. (Agamben 2009, p. 37)

This expanded sense of signature, which I will sometimes refer to by the Latin signatura to distinguish it from processes of autography, becomes indispensable when thinking about how pre-modern correspondence functioned, and how it recurs in the late nineteenth century. Eyebright does not resemble an eye in a way that implies a hierarchical order of representation. Instead, the herb and the organ together constitute a resemblance, detected and designated through a signature, which, in turn, can lead to other resemblances. It is not possible to alter a signature without also altering the relationship of which it is an expression, for "signature is no more than an intermediate form of the same resemblance" (Foucault 2002, p. 32). This is what Agamben means when he says that signifiers always already slide into the position of the signified, for signaturas are always coeval with the relationships they express. Signaturas form a system that spreads like a network over the earth, covering it in a lattice of interconnection.

Bloom flirts with some of these linguistic implications in "Lestrygonians" after imagining that the resemblance between the words "rat" and "vat" reflects the interaction between the animal and container. "Vats of porter wonderful. Rats get in too. [ ... ] Drink till they puke like Christians. Imagine drinking that! Rats: vats. Well, of course, if we knew all the things" (U 8.47-50). If only Bloom "knew all the things," if Stephen could only read "the signatures of all things," language would lose its transparency and neutrality. Instead, it would become possible to "uncover a language which God had previously distributed across the face of the earth," the "signature stamped upon things since the beginning of time" (Foucault 2002, p. 65). Part of a logic Hugh Kenner famously calls a comedy of "the inventory," Bloom's desire to arrange "all the things" recalls early-modern linguistic categorization (Kenner 1964, pp. 30-66). The sixteenth-century encyclopedia does not seek to reflect "the neutral element of language," but instead attempts "to reconstitute the very order of the universe by the way in which words are linked together and arranged in space" (Foucault 2002, p. 42). In this instance, the sonic proximity of the words "rat" and "vat" mirrors the spatial relations between rodents and porter barrels. One relationship does not precede the other. This expanded sense of signatory correspondence surfaces in Stephen's reflection on William Shakespeare's name and initials in "Scylla and Charybdis."

What's in a name? This is what we ask ourselves in childhood when we write the name we are told is ours. A star, a daystar, a firedrake, rose at his birth. It shone by day in 
the heavens alone, brighter than Venus in the night, and by night it shone over delta in Cassiopeia, the recumbent constellation which is the signature of his initials among the stars. (U 9.927-31)

At the end of the sixteenth century, Tycho Brahe discovered a supernova over the star Delta in the constellation Cassiopeia. Forming an "M" or "W" shape, the center of Cassiopeia rapidly brightened, eventually becoming visible during daylight. Shakespeare was a child at this time, and would have seen the shape of his initial in the sky. Placing written letters in continuity with celestial events, Joyce consolidates autography and astrology, showing that the question of "what's in a name" is not so different from asking "what's in the sky?" - both are attempts to derive knowledge from signatures imprinted upon the visible world (Gifford 1988, p. 244).

Shortly after alluding to Böhme in the beginning of "Proteus," Stephen draws upon the doctrine of signatures to sketch a relationship of resemblance. The signatures he "reads" on Sandymount Strand and the words he assigns to them (snotgreen, bluesilver, rust) rely upon a logic of signatura, for they visually describe the seascape but also give clues to its unseen effects on human and nonhuman bodies. A bather in the "snotgreen" sea might find his sinuses overcome with green mucous; submerging silver in the "bluesilver" water will cause a blue-green tarnish to form; the color "rust" arises from rusting, oxidized metal-a reaction that accelerates at the seashore. The chemical implications of these adjectives would not be lost on Böhme, who dwells extensively on the cosmological and alchemical relationships between sulphur, mercury, and salt (Boehme 1969, p. 31). Barbara DiBernard has shown how this alchemical fascination continues into Finnegans Wake, connecting the expression "signed with the same salt" to Johann Rudolf Glauber's De signatura salium (Joyce 1939, p. 168; DiBernard 1980, p. 74). In Joyce's own copy of Böhme's text, originally held in his Trieste library, there are no genetic traces that elucidate the author's depth of understanding or engagement with the doctrine of signatures (Böhme 1912). His copy of Aquinas's Summa contra gentiles, however, contains unverifiable annotations that reflect an interest in signatura. This text contains the doctrine of the medicine sacrament, a subset of Christian belief that stems from pre-modern theories of correspondence (Agamben 2009, p. 44). In Joyce's Latin copy, there are four marks next to a passage in Caput XX of Book III: Quomodo res divinam bonitatem imitentur [How Things Imitate Divine Goodness]. This idea is essential to the doctrine of signatures. For just as the external body manifests the inner state of the soul, or the earth mirrors the celestial movements of the heavens, the arrangement of things redoubles a divinely-prescribed order. Other annotations are more interested in worldly resemblances than divine. A double earmarked passage from earlier in the Summa describes how desire is founded upon similitude or likeness (Aquinas 1906, pp. 95-96, 280). The desirous implications of signature will be important when considering Bloom's message on Sandymount Strand.

\section{Autographic Implications}

The doctrine of signatures becomes historically relevant to Ulysses once it is noted that this kind of thinking had a resurgence during Joyce's early life. My contention is that Joyce's treatment of handwritten signatures folds in an older sense of signatura, creating an expanded version of the signatory act in which humans, animals, and nonhumans participate mutually. On the historical front, these ideas reappeared through "a gradual emergence under different names starting in the second half of the nineteenth century" (Agamben 2009, p. 20). The doctrine, I will argue, governed how autographic inscriptions were interpreted through the burgeoning "science" of graphology—a method of inquiry particularly appealing for Joyce.

If turn-of-the-century discourse surrounding handwritten signatures conceptually inherits an older doctrine of resemblance and correspondence, it is due, in large part, to certain advancements in the technology of writing. In Gramophone, Film, Typewriter, Friedrich Kittler shows how the invention of his study's three eponymous media formats produced certain changes in the way older media such as handwriting were viewed in relation to questions concerning reference. A few paragraphs after 
mentioning Leopold Bloom's fantasy in Ulysses that the dead be given telephones to prevent premature burial, Kittler turns his attention to the sensuality of handwriting.

Since 1865 (according to European accounts) or 1868 (according to American ones), writing has no longer been the ink or pencil trace of a body whose optical and acoustic signals were irretrievably lost, only to reappear (in readers' minds) in the surrogate sensuality of handwriting. (Kittler 1999, p. 13)

The advent of the typewriter led to a regulated expansion of graphic possibilities, as the font and typography of someone's personal machine replaced the idiosyncrasies of their personal script-a script carefully cultivated by Milly Boom by means of her handwriting copybook (U 17.1775). It is important to observe that even though word processing has largely supplanted the typewriter, it is still customary to sign one's signature upon the printed page. Handwriting captures something personal that is lost through the mechanization and regulation of type-namely a unique and irreproducible graphological personality, a signature. This treatment of handwriting contains an older sense of correspondence, through which a person's inner character surfaces in the inscription of alphabetic characters - revealing the shared etymology of these two homographs.

The conflation of signature and signatura occurs early in Ulysses, during Stephen's critique of Cyril Sargent's handwriting in "Nestor." Sargent, a boy whose "thick hair and scraggy neck gave witness of unreadiness" has stayed behind after class on the orders of Mr. Deasy to redo his sums (U 2.124-5). When Stephen inspects his copybook, he finds "sloping figures and at the foot a crooked signature with blind loops and a blot. Cyril Sargent: his name and seal" (U 2.129-30). Here "blind" evokes a buried sense of the word implying purposelessness and a lack of discernment, but also a letter written in a closed or filled-in manner. The opening of "Araby" employs the word in a similar sense, describing North Richmond Street as "blind": a road closed at one end (Joyce 1967, p. 29). When we remember, however, that Sargent gazes through "misty glasses" with "weak eyes," the blind loops take on an additional connotation of scopic deprivation (U 2.125). Likewise his "sloping figures" might slant across the page, but "slop" doubles for something that has been dashed on carelessly, evidenced by the "blot" that appears after his name. This graphic carelessness mirrors his unready appearance, underscored by a description of ink stains on Sargent's cheek, in which writing bleeds across facial features. "On his cheek, dull and bloodless, a soft stain of ink lay, dateshaped" (U 2.126). Here the adjectival phrase - carefully positioned between "cheek" and "stain"—could take either noun as its object. Sargent's cheeks are pale and bloodless, but the ink is also dull, blurred, and blotched. His facial features find a supplement through ink transfer, giving the impression that Sargent was written into existence. The signature "Cyril Sargent" is more than an arbitrary formality: the appearance of his alphabetic characters mirror the qualities and aspects of his personal characteristics.

Stephen's analysis rests upon an expanded sense of signatory congruency that Walter Benjamin terms "nonsensuous similarity": a correspondence that occurs across the senses rather than within the domain of the visual. The historic shift from resemblance to representation is less about paradigmatic regimes or scientific revolutions, he argues, more about the evolution of an innate mimetic faculty and its historic redistribution across the senses: "the mimetic power, and with it the gift of mimetic perception, have disappeared from certain fields-perhaps in order to follow into others." Noting that from "time immemorial, the mimetic faculty has been conceded some influence on language," Benjamin suggests that the doctrine of signatures never disappeared completely, but was instead transmuted into language (Benjamin 1999, pp. 695-97). Our ability to seamlessly move between writing and speech, to find compatibility between aural phonemes and inscribed graphemes, demonstrates a mimetic persistence of nonsensuous similarity that occurs between the human senses.

If, at the dawn of humanity, this reading from stars, entrails, and coincidences was reading per se, and if it provided mediating links to a newer kind of reading, as represented by runes, then one might well assume that this mimetic gift, which was earlier the basis for clairvoyance, very gradually found its way into language and writing in the course of a 
development over thousands of years, thus creating for itself in language and writing the most perfect archive of nonsensuous similarity. (Benjamin 1999, p. 697)

Benjamin provides an important update to the doctrine of signatures by allowing correspondence to be nonsensuous: handwriting does not have to visually resemble its inscriber in order to bear a trace of his signature. "In this way, language is the highest application of the mimetic faculty-a medium into which the earlier perceptual capacity for recognizing the similar had, without residue, entered to such an extent that language now represents the medium in which objects encounter and come into relation with one another" (Benjamin 1999, p. 697). Cyril Sargent's signature is not a literal portrait of its owner, but its resembles him, nevertheless, through a relationship of similitude, what Joyce formulates as "a mimograph" in Finnegans Wake (Joyce 1939, p. 467). The graphic act is always already entwined with mimesis, even if mimeographic duplication has been replaced by subtler forms of reproduction.

The Cyril Sargent passage flirts with the practice of handwriting interpretation, a particularly nineteenth-century fad. Graphology seeks the same personal investments Kittler attributes to written script at the very moment Agamben notes the resurgence of the doctrine of signatures. "Of course, typewriters that eliminated all the individuality of script had recently appeared," writes Kittler in Discourse Networks, "but a psychophysical graphology arose in a counter movement and focused on the difference between standardized letters and unconscious-automatic hands that write" (Kittler 1990, p. 215). The proliferation of textbooks and personal reflections on graphology at the end of the nineteenth century suggests a mechanism of resistance against the depersonalizing effects of typewriting. At the very moment when the optical and acoustic signals of handwriting were becoming irretrievably lost, a group of disparate writers began marketing graphology as a psychological science. Writing in 1933, Benjamin connects the rise of this technique to the older doctrine of correspondences.

The most recent graphology has taught us to recognize, in handwriting [ ... ] that the unconscious of the writer conceals in his writing. It may be supposed that the mimetic process which expresses itself in this way in the activity of the writer was, in the very distant times in which script originated, of utmost importance for writing. Script has thus become, like language, an archive of nonsensuous similarities, of nonsensuous correspondences. (Benjamin 1999, p. 697)

The first full-length work on graphology was The Mysteries of Handwriting: The Art of Judging Men from Their Autographs (1872) by Adolphe Desbarrolles and the Abbé Jean-Hippolyte Michon (Thornton 1996, p. 92). Shortly afterwards, The Philosophy of Handwriting (1879) by John Henry Ingram appeared in English. Adopting a nom de plume of Don Felix Salamanca for the occasion, the text collects dozens of signatures from figures such as Charles Darwin, Victor Hugo, Stéphane Mallarmé, William Morris, and Emile Zola, subjecting them to the "science" and "magic" of chiromancy. Ingram's text plays upon a slightly older Victorian phenomenon of the autograph book, a genre Edgar Allen Poe contributed to through a series of published analyses, concluding that "a strong analogy does generally and naturally exist between every man's chirography and character" (Irwin 2016, p. 44). J. Harington Keene's The Mystery of Handwriting: A Handbook of Graphology offers lessons on how to recognize "sanguine, bilious, and nervous" temperaments through handwriting, as well as subtler qualities such as aspiration, avarice, coquetry, lucidity, and tact (Keene 1896, p. 11). Simon Arke's Graphology: How to Read Character from Handwriting includes actual specimens of handwriting with facing pages of analysis. An "initial hook" on a letter " $b$ " connotes "a rapid and animated talker," while someone who writes their "s"-shapes "tightly closed" reveals a person "who can rarely be depended upon to be perfectly frank and straightforward in his business dealings" - a person, perhaps, like Cyril Sargent and his blind loops (Arke 1904, pp. 86, 101). John Rexford's What Handwriting Indicates: An Analytical Graphology features a section on signatures, which, for the graphologist, "may prove a gold mine or an ash heap." It is interesting to note that Rexford privileges the signature for its illegibility and spontaneity, writing that "the more unstudied the writing, the more truthfully it reflects 
the character of the writer" (Rexford 1904, p. 85). In her study of handwriting in America, Tamara Thornton builds upon this idea, drawing the useful distinction between speech and gesture.

For handwriting romantics, the gesture of handwriting was a revelation, even a betrayal of the innermost self. Handwriting was not a conscious component of the public self or a triumph of the will over the body in forming character. [ ... ] The theory and practice of handwriting analysis appealed to romantics because it posited just such a sanctuary for threatened individuality and presented handwriting as just such a wondrous exhalation. (Thornton 1996, p. 84)

Anticipating the Freudian unconscious, nineteenth-century graphology offers a revision to the notion that the unconscious is structured like a language. In graphology-which is, at its core, an attempt to systematize a nonsensous correspondence between writing and personality-the unconscious appears in calligraphic ornament, the formal qualities of writing to which we do not normally attribute semantic content.

Aware of signatory connotation to the point that they purposefully modify their script, both Joyce and Bloom attempt to forge distinct graphic personalities by manipulating their handwriting. In "Sirens," for example, Bloom not only signs his letters to Martha Clifford with the alias "Henry Flower," he deliberately misshapes his vowels. "Remember write Greek ees" (U 11.860-1). This graphic deception feeds into Bloom's trial by signature in "Circe," in which Mrs Bellingham describes how he addressed her "in several handwritings" ( $U$ 15.1045). The substitution of Greek and Latin letters was a technique Joyce himself employed in his secretive letters to Martha Fleischmann. As Ellmann notes, it "seems unlikely that he could have supposed that this slight change would be of any use in a court test of handwriting; it could have meant to him little more than a sign that he was reserving part of himself in the correspondence" (Ellmann 1982, p. 449). While Joyce may have been aware of his modification's futility before the law, it did not necessarily connote reserve. On the contrary, it probably signaled excess, as a graphic technique for conveying knowledge and education: the handwriting of a man steeped in the classics. This is, at least, the way Joyce will later gloss the act in the Finnegans Wake, where similar "ees" are discovered in Anna Livia Plurabelle's letter, demonstrating "the learning betrayed at almost every line's end" (Joyce 1939, p. 120).

\section{Nonhuman Signatures}

In "Nausicaa," Joyce splits signature from its onomastic, legal, and epistolary associations, crafting a wider definition that includes animal and inanimate participants. The nameless signature finds its most careful articulation in the climax of the episode, which occurs shortly after Bloom's self-induced climax at the sight of Gerty MacDowell. Walking along the water of the Sandymount Strand-the same location where Stephen meditated upon the signatures in "Proteus"—Bloom decides to write a note for Gerty in the sand. "Mr Bloom with his stick gently vexed the thick sand at his foot. Write a message for her. Might remain. What?" (U 13.1256-7). In thinking that the message might endure, Bloom invokes the lyric tradition of preservation fantasy, what Stephen calls "the spiritual-heroic refrigerating apparatus" - a tradition that Samuel Beckett will insert himself into and ultimately upend (Joyce 1964, p. 84; Dukes 2017). By writing a message for Gerty on the strand, Bloom assumes the position of Edmund Spenser's name-writer from "Amoretti LXXV," who contrasts writing on a "strand" with a more permanent form of nominal preservation.

One day I wrote her name upon the strand,

But came the waves and washèd it away:

Again I wrote it with a second hand,

But came the tide and made my pains his prey. (Spenser 1989, p. 75)

Both Spenser and Joyce associate sand with a form of eternity, for Stephen questions whether he is "walking into eternity along Sandymount Strand" ( $U$ 3.18). Sand becomes a material stand-in 
for oblivion in Spenser's poem, the negation of immortality, as it absorbs and washes away endless names traced upon its surface. The speaker sees himself in a condition of impending immanence akin to the effaced name- -bound to return to dust and oblivion, to re-join the sand completely. For his addressee, however, he envisions something different. By encoding her name in verse, he hopes to make her virtues eternal, an act equivalent to writing her name in heaven's immortal books. When a reader (like yourself) revisits Spenser's poem in centuries to come, "later life" renews their bond, which sustains a fantasy of preservation, if only in name. And yet, Spenser never records the name of his addressee. "The proper name is never given. This is the most important part about the poem" (Kunin 2009, p. 94). Instead of preservation, the poetic process meant to eternalize somehow achieves the exact opposite effect-it obfuscates, effaces, and generalizes all particulars. Spenser's apparent failure, however, opens onto an act of inclusion, as the poem holds true for any individual that assumes the feminine pronoun.

In an act of inscriptive self-definition, a kind of long-form signature, Bloom begins to write a phrase reminiscent of Exodus 3:14, or what Joyce will call "the ineffability of the tetragrammaton" in "Ithaca": "I. AM. A." (U 17.1900-1; 13.1258-64). In addition to its semantic content, the formal aspects of Bloom's inscription recall the technological history of writing. While sand is a medium that can accommodate cursive or rounded letters like " $\mathrm{d}$," " $\mathrm{b}$," and "o," Bloom chooses capital letters made from straight lines—an almost cuneiform-like script—recalling how writing originated through pressing styli into wet clay tablets, and later, chisels into hard stone (Fischer 2001, pp. 11-45). In "Ithaca," it will be revealed that both Stephen and Bloom share an interest in the history of writing - particularly the alphabet's shift away from mimetic resemblance towards abstracted, phonetic representation (U 17.769-773). Despite his graphic reserve, Bloom does not finish the sentence, leaving the signature incomplete.

In some ways, the failure of signature was Joyce's own. In multiple communications throughout his life, he hesitates over how exactly to sign himself (Culleton 1994, pp. 109-28). A letter to Nora, on 15 August 1904, ends with the question: "How am I to sign myself? I won't sign anything at all, because I don't know what to sign myself" (Joyce 1966, p. 47). This incompletion also mirrors Noisey Flynn's anti-Semitic claim that the Leopold refuses to sign documents so as not to be liable (U 8.988), as well as Bloom's recollection in "Sirens" that he never signed his letter to Martha (U 11.1080). The message to Gerty will not be deciphered, and Bloom never expresses what, in fact, he is. And yet, on the other hand, Bloom avoids closure, avoids the particular, by leaving his signature open to completion. Like Molly's life-affirming "yes" at the end of Ulysses, Bloom's self-definition is radically inclusive: he is a Dublin advertising man, a Greek war hero, an Irishman, a Hungarian Jew, and even (at moments) a woman.

From a forensic perspective, it is not necessary for Bloom to complete his sentence, for his actions will always bear a trace of his bodily signature. While Bloom's skin may seem to delimit the outer reaches of his body, he is constantly leaking identifiable traces in the form of scents and signs, recalling Michel Serres's observation that "the organism is a barrier of braided links that leaks like a wicker basket but can still function as a dam" (Serres 1982, p. 75). It is no coincidence that moments before writing in the sand, Bloom contemplates the excremental signatures of animals. "Dogs at each other behind. Good evening. Evening. How do you sniff? [ ... ] Animals go by that. Yes now, look at it that way. We're the same" (U 13.1029-31). In an equation that Joyce repeats throughout Ulysses, Bloom connects the written name to a kind of excremental signature-a unique, territory-claiming excretion of the human body. Mulligan's name "stinks all over Dublin" (U 6.64-5); "fragrant names" waft like incense in "Nausicaa" ( $U$ 13.372). Martha wants to know what kind of perfume Molly uses, as if to challenge her olfactory, territorial claims (U 5.258). Even Bloom's identity is not immune. In "Cyclops," a pub goer makes a similar, albeit racist and derogatory observation akin to Bloom's comment about the dogs: "those jewies does have a sort of queer odour coming off them for dogs about I don't know what all deterrent effect and so forth and so on" (U 12.453). Identity bleeds across the porous borders of the body, in the form of names, handwriting, and scent. For Serres, the autographic signature is 
an advanced form of excremental appropriation. "To make something its own, the body knows how to leave some personal stain," he writes. Offering a list of different kinds of bodily pollutions, which includes "sweat on a garment," "waste in space," "aroma," and "excrement," he then connects these acts to the signing of signatures-"my signature looks sweet and innocent, seemingly unrelated to those habits. And yet ... " (Serres 2011, pp. 2-3). Like a dog claiming its territory, the name-writer covers a surface with her mark to prohibit others from doing the same-a process that will be explicitly linked to writing in Finnegans Wake through Shem the Penman's "inkenstink" (Joyce 1939, p. 183).

Ultimately, standing on Sandymount Strand, Bloom decides to efface the partial inscription. Bloom's justification resides in the fact that if the message remains, it will probably be rendered "useless" by pedestrian traffic—-which Stephen earlier describes as "splayed feet sinking in the silted sand" (U 3.31).

Some flatfoot tramp on it in the morning. Useless. Washed away. Tide comes here. Saw a pool near her foot. Bend, see my face there, dark mirror, breathe on it, stirs. All these rocks with lines and scars and letters. [ . . ] Bloom effaced the letters with his slow boot. Hopeless thing sand. Nothing grows in it. All fades. [ . . . ] He flung his wooden pen away. The stick fell in silted sand, stuck. (U 13.1259-71)

Joyce anticipates a meaning of "tramp" that develops later in the twentieth century, using the word to describe both the adulteration of Bloom's virginal Gerty and the trampling of his message. While footprints seem at odds with signature, they do not efface, so much as superscribe his sandy text, creating a palimpsest of inscription. In Bloom's projected future, he bends over the water-filled footprint and sees his own face gazing back. The image cryptically suggests that the "I AM A" sentence is completed, or even redoubled, through Bloom's narcissus-like reflection. Joyce will undermine this reflexivity in "Circe," an act anticipated by Buck Mulligan's description of Caliban's rage at not seeing his face in a mirror $(U$ 1.143). When Stephen and Bloom gaze into a mirror together, they see the face of William Shakespeare, "beardless [ . . ] rigid in facial paralysis" gazing back (U 15.3821-4). Like Stephen's well-known quip that the symbol of Irish art is the "cracked lookingglass of a servant" (U 1.156), "Circe" cracks the trope of art being a mirror held up to nature. In doing so, Joyce shows how signatory reflexivity comes under question in his work. Bloom and Stephen gaze into the mirror and see The Bard looking back, just as a reader may open Ulysses and find a bricolage of source-texts (including, of course, Shakespeare) supplementing the signature affixed to Joyce's prose.

Admitting the hopelessness of preservative inscription by commenting upon sand's adversity to life, Bloom flings his makeshift stylus to the ground. Improbably, the stick sticks, remaining visible, distinct and erect. Both a sexualized conclusion to Bloom's masturbatory encounter and a commentary upon the penetrative properties of inscription, the "stick" which falls into the "silted sand, stuck," enacts Marion's claim in "Circe" that Bloom is "a poor old stick in the mud!" (U 15.329-30). He may be unadventurous and resistant to change, but this epithet becomes Bloom's visual signature. He completes his signatory declaration, not through alphabetic writing, but with a simple act of marking, embossing his presence upon the strand. This reading is supported by certain textual echoes between the Sandymount scene and the description of Cyril Sargent's signatura in "Nestor." Moments before this earlier passage, we find a description of schoolyard play ("a stick struck the door")—whose content and sibilance seems to anticipate Bloom's stick stuck in silted sand (U 2.118). Several sentences later, Stephen reflects that, without Sargent's loving mother, the world would have "trampled him underfoot," the very action Bloom fears will befall his inscription on the beach (U 2.142).

Demonstrating an entanglement reminiscent of the doctrine of signatures, Bloom and his stick share an unlikely affinity with Stephen and his ashplant-which "marks his stride" in "Circe," shortly after Bloom "snatches up" the cane to try it for himself ( $U$ 15.4328/4278). In "Ithaca," a concrete poem solidifies the parallel between Bloom's stick and Stephen's ashplant. "Light Candle in Stick / borne by / Bloom / Diaconal Hat on Ashplant / borne by / Stephen" (U 17.1023-8). While the stick becomes a signature of resemblance between Bloom and Stephen, it also connects Bloom to Ulysses. "A certain Ulysses, sitting one day on the shore of the nymph of Circe's island, wrote with his stick in the sand," 
Joyce recalled in a letter to Lucia (Joyce 1957, p. 369). The stick serves as a four-dimensional signature, a hieroglyphic link between Bloom's day in Dublin and its mythic, Homeric origins.

It is not only humans, however, who sign themselves upon Sandymount Strand. As William Viney observes, "the beach appears heavy with linguistic deposits" (Viney 2014, p. 109). Recall that Bloom's scene of signature occurs in the same place where Stephen reads the signatures "of all things" earlier in the novel—where he hears "fourworded wavespeech—a moment that occurs shortly after he sees "[w]avewhite wedded words shimmering on the dim tide" (U 3.456-7; 1.246). Observing "lines, scars, and letters" in the beach's stone, Bloom also recognizes the nonhuman world's capacity to perform a kind of writing, which he himself mirrors in the scene's conclusion. Just a few pages before, Bloom reflects on how the sun "wants to stamp his trademark on everything"-indicating that the source of life itself may be this enlarged sense of signature ( $U$ 13.875). Bloom's vision of lithic striation as a form of language also recalls an earlier moment in Ulysses, when Stephen reflects upon the semiotic quality of Sandymount's geology: "heavy sands are language tide and wind have silted here" (U 3.288-9). By displacing sand with his stick, Bloom participates in Stephen's "language tide," momentarily entering a discourse larger than his own. Nonhuman writing appears in a different form during "Sirens," when musical instruments are likened to a cacophony of wild animals. "Brasses braying asses through uptrunks. Doublebasses helpless, gashes in their sides. Woodwinds mooing cows. Semigrand open crocodile music hath jaws" (U 11.1053-5). While the animal instruments "speak" rather than write, the musical "score" in "Ithaca" - which evokes the inscriptive act of scoring a surface-demonstrates the ease with which these personifications find transcription, likened to a kind of cuneiform writing in Finnegans Wake: "a meusic before her all cunniform letters" (Joyce 1939, p. 198).

Ulysses is full of animal and inanimate entities participating in speech and writing, signing themselves upon the world. Perhaps the most well-known example can be found in "Aeolus," when a printing machine calls attention to itself. "Sllt. Almost human the way it sllt to call attention. Doing its level best to speak. That door too sllt creaking, asking to be shut. Everything speaks in its own way. Sllt" (U 7.174-6). For the sake of this argument, Bloom's observation might be narrowed slightly. When the printing press "sllts," it is less conversational, more signatory. Like a dog marking its territory, the machine appropriates space through auditory production, what Serres calls "soft pollution" (Serres 2011, p. 41), drawing attention to itself. While the printing press becomes "almost human" through its approximation of spoken language, elsewhere in Ulysses this process is reversed, as humans take up the sounds and signs of the nonhuman world. David Rando has argued that it is impossible to write about language in Ulysses without "reinforcing the precise linguistic basis that maintains the barrier" between humans and the nonhuman world. I want to disagree, however, and argue that Joyce's expanded sense of signature offers a way through the problem of language, "the very barrier upon which a long philosophical and scientific tradition" has constituted taxonomic differences between humans and other entities (Rando 2009, p. 531).

If signing (as opposed to speaking) is read as the primal scene of language emergence, humans, animals, and objects are thrust into a newly flattened ontology. In the allusion rich pages of "Oxen of the Sun," the lord Harry desires to learn the language of the bull. After discovering in himself a "wonderful likeness to a bull," he buys "a grammar of the bulls' language to study" (U 14.626/633-4). Unable to learn anything except for "the first personal pronoun," he nevertheless promptly fills his pockets with chalk "to write it upon what took his fancy" (U 14.635-7). The first personal pronoun recalls Bloom's declaration of "I AM A" - both are a kind of shorthand for the signatory act: the inscription of " $\mathrm{I}$ " upon the world. The animal language also plays upon ideas surrounding the papal bull and the Irish bull, linked to Stephen's later description of "an Irish bull in an English chinashop" (U 14.581). More obliquely, the scene offers an opaque restaging of the doctrine of signatures, in which humans, animals, and objects are continually signing themselves in acts of mutual resemblance and relationship. Here we find the conclusion to Stephen's nickname in Portrait: "Bous Stephanoumenos! Bous Stephaneforos!" (Joyce 1964, p. 168). Translating as "crowned" or "garland-bearing" bull, this schoolyard banter anticipates Stephen's later fascination with the alphabet in Ulysses. 
When thinking about bulls and oxen, it is important to remember that both Stephen and Bloom are interested in the historical evolution of alphabetic writing - the "increasing simplification traceable from the Egyptian epigraphic hieroglyphs to the Greek and Roman alphabets" (U 17.770-1). In the early Semitic alphabets, aleph, from which the Greek alpha and Roman "A" descends, still resembled Egyptian hieroglyphs of oxen-a fact that would have been in Joyce's mind while composing "Oxen of the Sun". Over several thousand years, the character rotated $180^{\circ}$, and the horns of the ox became abstracted into the diagonal stems of an "A" (Moorhouse 1953, p. 101). All the letters of the Semitic alphabet originate through similar visual correspondences. Contrasted to the phonetic alphabet, "[t]he pictographic glyph or character still referred, implicitly, to the animate phenomenon of which it was the static image" (Abram 1996, p. 100). Perhaps this hieroglyphic sense helps explain what Joyce meant, when, during a conversation with Arthur Power about his walks through the British Museum, he supposedly commented that "the Egyptians understood better than we do the mystery of animal life" (Power and Joyce 1996, p. 63). The mystery of animal life and alphabetic origins are intimately entwined.

To write an " $\mathrm{A}$ " harkens back to a sensuous correspondence between writing and the world, as Stephen recognizes in "Proteus." "The cords of all link back, strandentwining cable of all flesh. That is why mystic monks. Will you be as gods? Gaze in your omphalos. Hello. Kinch here. Put me on to Edenville. Aleph, alpha: nought, nought, one" (U 3.37-40). In a fantastic cascade of thought, Stephen's umbilical cord becomes a telephone cable stretching back to Eve. To reach "Edenville" he dials "Aleph, alpha"-demonstrating that the evolution of the alphabet is another "cord" that links us back to the origins of language, when something came from nothing, when "nought" and "nought" became "one." In this argument, whenever we write the letter " $\mathrm{A}$," we are drawing an abstracted image of an ox-a signatory action alike in kind to lord Harry emblazoning a bull's first person pronoun on "the side of a rock," "a teahouse table," or "a bale of cotton or corkfloat" (U 14.637-8). While language may reach back to the Adamic scene of naming, Joyce suggests that language arose out of the ox rather than being imposed upon it. The transmission and historical evolution of the alphabet is contingent upon a process of nonhuman collaboration. Joyce nuances Bloom's observation that "everything speaks in its own way." Human signature speaks through sticks and oxen, the evocation of animal and nonhuman forms, recalling a world in which language seemed inseparable from the things it described.

\section{Conclusive Evidence}

The mysterious vision of language and signature belonging equally to the human and nonhuman squares with a comment Joyce would make to Weaver upon the publication of Ulysses. "In conception and technique I tried to depict the earth which is prehuman and presumably posthuman" (Joyce 1966, p. 289). Joyce not only expands signature to include marking, geologic processes of striation, and the penetration of bodies by ultraviolet light, but the subject field expands as well. Bloom writes in sand, while the sun writes on him. The signatures on Sandymount Strand and Cyril Sargent's autograph differ only in medium. Serres describes this process, by which the material world encodes itself, as a kind of auto-inscription. "But, once again, who has memory? Tradition replies: humans, in their cognition, their mnemonic faculty, their traces, written, engraved or drawn, those they decipher. No, for things themselves memorise, by themselves and directly. The past is inscribed in them, it is enough to decipher it from them" (Serres 2003, p. 70). For Bloom, there is a signatory language that exists before and after human discourse, which both facilitates and makes possible the act of inscription. Ideas are articulated through letters, which once resembled animals, set down in sand with a stick. In this chain, signature becomes a collaborative process between humans, animals, and inanimate materials_-impossible without a comingling between unlikely participants.

Joyce takes this line of argument to its extreme in Finnegans Wake, asking why sign anything at all, when our actions, bodies, and its objects always already leave behind a signature, like footprints in the sand. In the Wake, Anna Livia Plurabelle's letter is inundated with signatures, both intentional and accidental. 
after the battle of the Boyne it was a habit not to sign letters always. [ ... ] The end? Say it with missiles then and thus arabesque the page. You have your cup of scalding Souchong, your taper's waxen drop, your cat's paw, the clove or coffinnail you chewed or champed as you worded it, your lark in clear air. So why, pray, sign anything as long as every word, letter, penstroke, paperspace is a perfect signature of its own? (Joyce 1939, p. 114)

Signature becomes a form of forensic excrement, a precursor to DNA evidence. The choice of words, the shape of letters, penstrokes, and the spatial occupation of "paperspace" all carry identifiable graphic styles, capable of analysis and recognition. One can write their name upon the page; they can spill "scalding Souchong" across its surface; or seal it with a "taper's waxen drop." These signatory techniques are equated to the marks left by a "cat's paw" or the unique bite pattern on "the clove or coffinnail you chewed or champed." Like arabesque designs, signature expands beyond letters, becoming a series of reflexive marks left upon the world-by teeth, paws, or pencils. And yet, the final sentence can be read another way too, further complicating this expanded definition. If things themselves can memorize, is my signature ever really mine? Or, does every word, letter, and penstroke sign "a perfect signature of its own" - an updated version of the doctrine of signatures. This ambiguity is at the heart of Joyce's own signatory doctrine. To sign my name upon the world always requires a receptive surface and an impressive implement, as well as an alphabetical system that has descended from a system of hieroglyphic resemblance. These technologies and materials, in turn, leave their own trace upon my signature, making the act of signing into process of collaboration rather than individuation.

Conflicts of Interest: The author declares no conflict of interest.

\section{References}

Abram, David. 1996. The Spell of the Sensuous: Perception and Language in a More-than-Human World. New York: Pantheon.

Agamben, Giorgio. 2009. The Signature of All Things: On Method. Cambridge: MIT Press.

Aquinas, Thomas. 1906. S. Thomae Aquinatis Summa Philosophic: Seu, De Veritate Catholicae Fidei Contra Gentiles. Paris: P. Lethielleux. Harry Ransom Center. University of Texas, Austin. James Joyce Trieste Library, BX 1749 T4134 1906 JJT.

Arke, Simon. 1904. Graphology: How to Read Character from Handwriting. Washington: American Institute of Graphology.

Benjamin, Walter. 1999. Selected Writings 1931-1934. Edited by Michael Jennings, Howard Eiland and Gary Smith. Translated by Rodney Livingstone. Cambridge: Harvard University Press, vol. 2, Part 2.

Boehme, Jacob. 1969. The Signature of All Things and Other Writings. Cambridge and London: James Clarke \& Co. Böhme, Jakob. 1912. The Signature of All Things, with Other Writings. London: J.M. Dent \& Sons. Harry Ransom Center. University of Texas, Austin. James Joyce Trieste Library, BV 5080 B64 E3 JJT.

Culleton, Claire. 1994. Names and Naming in Joyce. Madison: University of Wisconsin Press.

DiBernard, Barbara. 1980. Alchemy and Finnegans Wake. Albany: SUNY University Press.

Dukes, Hunter. 2017. Samuel Beckett and the fantasy of lithic preservation. Irish Studies Review 25: 24-41. [CrossRef] Ellmann, Richard. 1982. James Joyce. Oxford: Oxford University Press.

Fischer, Steven. 2001. A History of Writing. London: Reaktion.

Foucault, Michel. 2002. The Order of Things: An Archaeology of the Human Sciences. London: Routledge.

Gifford, Don. 1988. Ulysses Annotated: Notes for James Joyce's Ulysses, 2nd ed. Berkeley: University of California Press. Irwin, John. 2016. American Hieroglyphics: The Symbol of the Egyptian Hieroglyphics in the American Renaissance. Baltimore: Johns Hopkins University Press.

Jaurretche, Colleen. 1997. The Sensual Philosophy: Joyce and the Aesthetics of Mysticism. Madison: University of Wisconsin Press.

Joyce, James. 1939. Finnegans Wake. New York: Viking Press.

Joyce, James. 1957. Letters of James Joyce. Edited by Stuart Gilbert. New York: Viking, vol. I. 
Joyce, James. 1964. A Portrait of the Artist as a Young Man. Corrected from Dublin Holograph by Chester G. Anderson. Edited by Richard Ellmann. New York: Viking Press.

Joyce, James. 1966. Letters of James Joyce. Edited by Richard Ellmann. London: Faber \& Faber, vol. II.

Joyce, James. 1967. Dubliners. Edited by Robert Scholes and Richard Ellmann. New York: Viking Press.

Joyce, James. 1986. Ulysses. Edited by Hans Walter Gabler, Wolfhard Steppe and Claus Melchior. New York: Random House.

Keene, J. Harrington. 1896. The Mystery of Handwriting: A Handbook of Graphology. Boston: Lee and Shepard.

Kenner, Hugh. 1964. Flaubert, Joyce, and Beckett: The Stoic Comedians. London: W.H. Allen.

Kittler, Friedrich. 1990. Discourse Networks 1800/1900. Translated by Michael Metteer, and Chrus Cullens. Stanford: Stanford University Press.

Kittler, Friedrich. 1999. Gramophone, Film, Typewriter. Translated by Geoffrey Winthrop-Young, and Michael Wutz. Redwood City: Stanford University Press.

Kunin, Aaron. 2009. Shakespeare's Preservation Fantasy. PMLA 124: 92-106. [CrossRef]

Moorhouse, Alfred. 1953. The Triumph of the Alphabet: A History of Writing. New York: H. Schuman.

Power, Arthur, and James Joyce. 1996. Conversations with James Joyce. Dublin: Lilliput.

Rando, David. 2009. The Cat's Meow: Ulysses, Animals, and the Veterinary Gaze. James Joyce Quarterly 46: 529-43. [CrossRef]

Rexford, John. 1904. What Handwriting Indicates: An Analytical Graphology. New York: G.P. Putnam's Sons.

Serres, Michel. 1982. Hermes: Literature, Science, Philosophy. Edited by Josué V. Harari and David F. Bell. Baltimore: John Hopkins University Press.

Serres, Michel. 2003. L'incandescent. Translated by Steven Connor in private correspondence. Paris: Le Pommier. Serres, Michel. 2011. Malfeasance: Appropriation through Pollution? Translated by Anne-Marie Feenberg-Dibon. Redwood City: Stanford University Press.

Siegert, Bernhard. 2015. Cultural Techniques: Grids, Filters, Doors, and Other Articulations of the Real. Translated by Geoffrey Winthrop-Young. New York: Fordham University Press.

Spenser, Edmund. 1989. Spenser's Shorter Poetry. Edited by William Oram, Einar Bioryind and Ronald Bond. New Haven: Yale University Press.

Thornton, Tamara. 1996. Handwriting in America: A Cultural History. New Haven: Yale University Press. Viney, William. 2014. Waste: A Philosophy of Things. London: Bloomsbury.

(C) 2017 by the author. Licensee MDPI, Basel, Switzerland. This article is an open access article distributed under the terms and conditions of the Creative Commons Attribution (CC BY) license (http://creativecommons.org/licenses/by/4.0/). 